\title{
Immunoassay of serum alpha-1 antitrypsin level in uveitis
}

\author{
A. K. GUPTA AND G. S. SARIN \\ From Guru Nanak Eye Centre, Maulana Azad Medical College, New Delhi, India
}

SUMMARY The serum alpha-1 antitrypsin level was measured in 60 patients with endogenous uveitis, 27 patients with phacoallergic endophthalmitis, 12 patients with phacolytic glaucoma, and 58 healthy subjects. Thirty-four patients with endogenous uveitis were also followed up for 6 months after treatment, and the serum alpha- 1 antitrypsin level was measured again. There was a significant rise in the serum alpha-1 antitrypsin level in cases of endogenous uveitis and phacoallergic endophthalmitis but no alteration in cases of phacolytic glaucoma. Among the patients with endogenous uveitis the level was significantly raised in cases of anterior uveitis, but there was no change in cases of posterior uveitis. A significant rise was seen only in cases of acute anterior uveitis but not in chronic anterior uveitis. The serum alpha-1 antitrypsin level was unaltered in endogenous uveitis despite clinical improvement.

Inflammatory diseases of the eye may lead to severe impairment of vision and even complete loss of ocular function because of the development of secondary glaucoma, complicated cataract, cyclitic membrane, secondary retinal detachment, and phthisis bulbi.'

Lens proteases liquefy the lens cortex to such a degree that lens material may escape through the capsule. Alpha-1 antitrypsin, a glycoprotein, is the major nonspecific protease inhibitor, synthesised by hepatocytes. ${ }^{2}$ Serum alpha-1 antitrypsin (alpha-1 antiprotease) is frequently increased in malignancy, ${ }^{3}$ acute infections, ${ }^{+}$corticosteroid therapy, ${ }^{5}$ rheumatoid arthritis," pregnancy, ${ }^{7}$ oral contraceptive administration, ${ }^{8}$ oestrogen therapy, ${ }^{9}$ sarcoidosis, ${ }^{10}$ and leprosy." Serum immunoglobulins have been reported to be altered in uveitis. ${ }^{12-14}$ There is good evidence that alpha-1 antitrypsin is involved in the regulation of the immune system. ${ }^{15}$ In the present study the serum alpha-1 antitrypsin levels have been evaluated in patients with uveitis and the effect of therapy on its level have also been studied.

\section{Material and methods}

Sixty patients with endogenous uveitis, 27 with phacoallergic endophthalmitis, and 12 with phacolytic

Correspondence to Dr A. K. Gupta, VI/6 Maulana Azad Medical College Campus, Kotla Road, New Delhi 110002 , India. glaucoma were studied for the immunoassay of serum alpha-1 antitrypsin level. The control group comprised 58 healthy subjects who had no evidence of ocular or systemic disease and attended the Eye Centre mainly for the purpose of refraction. The diagnosis of uveitis was established by detailed clinical examination, slit-lamp biomicroscopy, and direct and indirect ophthalmoscopy. Cases of uveitis, associated with hypermature cataract, exposure of lens matter into aqueous humour following trauma, needling, or extracapsular extraction were categorised as phacoallergic endophthalmitis clinically. They showed lid oedema, ciliary congestion, iris oedema, posterior synechiae, and numerous large keratic precipitates.

The age and sex distribution of all the subjects is given in Table 1 . The sera samples were stored at $-20^{\circ} \mathrm{C}$ until assayed. The alpha- 1 antitrypsin level in serum was measured by a single radial immunodiffusion technique using monospecific goat antiserum against human alpha- 1 antitrypsin and the reference standard obtained from Meloy Laboratories, Virginia, USA. ${ }^{16}$ The alpha-1 antitrypsin level was calculated from the calibration curve constructed by incorporating 3 known concentrations of reference standard.

Thirty-four patients with endogenous uveitis were followed up for 6 months after treatment consisting of local and systemic steroids, oral phenylbutazone, 
Table 1 Age and sex distribution in healthy subjects and diseased states

\begin{tabular}{|c|c|c|c|c|c|c|c|c|}
\hline & \multicolumn{5}{|c|}{ Age in years } & \multicolumn{2}{|l|}{ Sex } & \multirow{2}{*}{$\begin{array}{l}\text { Total no. of } \\
\text { subjects }\end{array}$} \\
\hline & $10-20$ & $21-40$ & $41-60$ & $\begin{array}{l}61 \text { and } \\
\text { over }\end{array}$ & Mean $\pm S D$ & Male & Female & \\
\hline Healthy subjects & 3 & 37 & 16 & 2 & $34 \cdot 6 \pm 10 \cdot 2$ & 36 & 22 & 58 \\
\hline Endogenous uveitis & 4 & 34 & 19 & 3 & $35 \cdot 8 \pm 12 \cdot 4$ & 34 & 26 & 60 \\
\hline Phacoallergic endophthalmitis & () & 6 & 11 & 10 & $57 \cdot 1 \pm 18 \cdot 2$ & 19 & 8 & 27 \\
\hline Phacolytic glaucoma & () & () & 11 & 1 & $56 \cdot 8 \pm 3 \cdot 0$ & 8 & 4 & 12 \\
\hline
\end{tabular}

mydriatics, and cycloplegics. A repeat measurement of serum alpha-1 antitrypsin level was done on patients with endogenous uveitis after clinical improvement.

\section{Results}

The serum alpha-1 antitrypsin levels in the healthy subjects and in the patients with uveitis are given in Table 2. A significant rise in the level was observed in endogenous uveitis $(p<0.001)$ and phacoallergic endophthalmitis $(p<0 \cdot 001)$. However, there was no significant change $(p>0.5)$ in its level in phacolytic glaucoma in comparison with the level in healthy subjects. Table 3 shows the serum alpha- 1 antitrypsin level in the different subgroups of endogenous uveitis. The serum alpha- 1 antitrypsin level was raised in the subgroup of anterior uveitis $(p<0 \cdot 001)$. However, in the subgroup of posterior uveitis there was no significant change $(p>0 \cdot 3)$. The patients with anterior uveitis were further subdivided into acute anterior and chronic anterior uveitis (Table 3). The serum alpha-1 antitrypsin level was significantly increased in acute anterior uveitis $(p<0.001)$ but unaltered $(p>0.2)$ in chronic anterior uveitis in comparison with the level in healthy subjects.

Table 4 shows the comparative serum alpha- 1 antitrypsin levels in patients with endogenous uveitis prior to treatment and after the treatment when there was clinical improvement. No significant change was seen in its level after treatment in any group.

\section{Discussion}

Several proteolytic enzymes are liberated in human serum during bacterial infections. ${ }^{17}$ The action of these proteases is modulated by various protease inhibitors like alpha-1 antitrypsin, alpha-1 antichymotrypsin, interalpha trypsin inhibitor, antithrombin-2, C-1 inactivator, and alpha-2 macroglobulin. ${ }^{18}$

The serum alpha-1 antitrypsin level in the healthy subjects $(199.9 \mathrm{mg} / \mathrm{dl})$ is lower than the values reported elsewhere from India, being $225 \mathrm{mg} / \mathrm{dl}$ " and
Table 2 Serum alpha-I antitrypsin level in healthy subjects and diseased states

\begin{tabular}{lll}
\hline & $\begin{array}{l}\text { No. of } \\
\text { subjects }\end{array}$ & $\begin{array}{l}\text { Alpha-l } \\
\text { antitrypsin } \\
\text { level }(\mathrm{mg} / \mathrm{dl})\end{array}$ \\
\hline Healthy subjects & 58 & $199 \cdot 9 \pm 54 \cdot 9$ \\
Endogenous uvcitis & 60 & $233 \cdot 2 \pm 56 \cdot 0$ \\
Phacoallergic endophthalmitis & 27 & $241 \cdot 8 \pm 64 \cdot 3$ \\
Phacolytic glaucoma & 12 & $187 \cdot 4 \pm 49 \cdot 6$ \\
\hline
\end{tabular}

SI conversion: $\mathrm{mg} / \mathrm{dl} \times 0 \cdot 01=\mathrm{g} / \mathrm{l}$.

Table 3 Serum alpha-I antitrypsin level in different subgroups of endogenous uveitis patients

\begin{tabular}{lll}
\hline & $\begin{array}{l}\text { No. of } \\
\text { subjects }\end{array}$ & $\begin{array}{l}\text { Alpha-l } \\
\text { antitrypsin } \\
\text { level (mg/dl) }\end{array}$ \\
\hline Anterior uveitis & 46 & $239 \cdot 5 \pm 55 \cdot 4$ \\
Acutc & 29 & $241 \cdot 8 \pm 57 \cdot 6$ \\
Chronic & 17 & $220 \cdot 2 \pm 46 \cdot 6$ \\
Postcrior uveitis & 14 & $221 \cdot 8 \pm 63 \cdot 1$ \\
\hline
\end{tabular}

SI conversion: $\mathrm{mg} / \mathrm{dl} \times \mathbf{0} \cdot 0 \mathrm{l}=\mathrm{g} / \mathrm{l}$.

$266.4 \mathrm{mg} / \mathrm{dl} .{ }^{19}$ In Western series, however, the serum alpha-1 antitrypsin level has been reported to vary between 180 and $400 \mathrm{mg} / \mathrm{dl}^{20-22}$ (SI conversion: $\mathrm{mg} / \mathrm{dl} \times 0 \cdot 01=\mathrm{g} / \mathrm{l}$.)

There is a remarkable elevation of the serum alpha-1 antitrypsin level in endogenous uveitis and phacoallergic endophthalmitis. The rise in the level of serum alpha-1 antitrypsin was significant in acute anterior uveitis. However, cases of posterior uveitis and chronic anterior uveitis did not show any significant alteration in its level. The elevated serum alpha1 antitrypsin level in patients with endogenous uveitis did not show any appreciable fall in spite of the clinical improvement. This could be explained by the fact that these patients were on systemic corticosteroids, which are known to increase the serum alpha-1 antitrypsin level, ${ }^{5}$ or it might be due to the persistence of subclinical activity of endogenous uveitis. It has been reported that there is no signifi- 
Table 4 Serum alpha-1 antitrypsin level in endogenous uveitis patients before and after therapy

\begin{tabular}{|c|c|c|c|c|}
\hline & \multirow[t]{2}{*}{$\begin{array}{l}\text { No. of } \\
\text { subjects }\end{array}$} & \multicolumn{2}{|c|}{$\begin{array}{l}\text { Alpha-l antitrypsin level } \\
\text { (mg/dl) }\end{array}$} & \multirow[t]{2}{*}{$p$ Value } \\
\hline & & $\begin{array}{l}\text { Before } \\
\text { therapy }\end{array}$ & $\begin{array}{l}\text { After } \\
\text { therapy }\end{array}$ & \\
\hline Anterior uvcitis & 25 & $233 \cdot() \pm 45 \cdot()$ & $226 \cdot 8 \pm 41 \cdot 1$ & $>0) \cdot 7$ \\
\hline Acutc & 16 & $239 \cdot 5 \pm 47 \cdot 5$ & $227 \cdot 5 \pm 37 \cdot 8$ & $>0 \cdot 5$ \\
\hline Chronic & 9 & $221 \cdot 4 \pm 4() \cdot()$ & $225 \cdot 6 \pm 48 \cdot 8$ & $>0.9$ \\
\hline Posterior uvcitis & 9 & $22(0 \cdot() \pm 33 \cdot 6$ & $218 \cdot 3 \pm 45 \cdot 9$ & $>0.95$ \\
\hline Total no. of patients & 34 & $229 \cdot 6 \pm 42 \cdot 2$ & $224 \cdot 5 \pm 41 \cdot 9$ & $>0.7$ \\
\hline
\end{tabular}

SI conversion: $\mathrm{mg} / \mathrm{dl} \times(\mathbf{0} \cdot(\mathbf{0}=\mathrm{g} / 1$.

cant association of the alpha- 1 antitrypsin phenotype variant $M Z$ with uveitis. ${ }^{23-24}$

A few studies have been reported on the serum alpha-1 antitrypsin level in different eye diseases. It has been suggested that bacterial infections of the conjunctiva increase the level of alpha-1 antitrypsin in tears, and measurement of its level may be an effective help in the diagnosis of ocular inflammation. ${ }^{25}$ The serum alpha-1 antitrypsin level has been reported to be low in cataract patients. ${ }^{26}$ In patients with phacolytic glaucoma alteration in the serum alpha-1 antitrypsin level was not seen, which agrees with the lack of clinical and cellular inflammatory response seen in patients with phacolytic glaucoma. The serum and tear alpha- 1 antitrypsin levels have been reported to be high in patients with corneal ulcer. ${ }^{27}$ Alpha-1 antitrypsin acts like an acute-phase reactant and its level tends to rise in inflammatory conditions. ${ }^{28}$ It has been observed that because of the acute reactant nature of this protein its serum concentrations may change dramatically in the presence of inflammatory processes and the growth of malignant tumours. ${ }^{2}$ The protease inhibitors may also have a protective action." During infections alpha-1 antitrypsin production increases to counteract endogenous or exogenous protease. ${ }^{29.31}$ It is possible that there is an excessive load of protease in circulation in uveitis, which may be counterbalanced by the release of alpha-1 antitrypsin.

\section{References}

1 Lerman S. Basic ophthalmology. New York: McGraw Hill, 1966: 306.

2 Morse JO. Alpha-1 antitrypsin and serum albumin. $N$ Engl $J$ Med 1978; 299: 1045-8.

3 Clark DG, Clifton EE, Newton BL. Antiproteolytic activity of human serum with particular reference to its changes in the presence and consideration of its use for detection of malignant neoplasia. Proc Soc Exp Biol Med 1948; 69: 276-83.

4 Jacobsson K. Studics on the determination of fibrinogen in human blood plasma in studies on trypsin and plasmin inhibitors in human blood serum. Scand J Clin Lab Invest 1955; 14 (suppl): 57-102.
5 Faarvang HJ, Lauritsen OS. Relationship between serum concentration and urinary output of trypsin inhibitor after cortisone administration. Scand J Clin Lab Invest 1963; 15: 483-90.

6 Cleve H, Bchrend T. Quantitative immunological determination of alpha- 1 acid glycoprotein and alpha- 1 antitrypsin in the sera of paticnts with rhcumatoid arthritis. Z Rheumatol 1966; 25: 278-83.

7 Ganrot PO, Bjerre B. Alpha-1 antitrypsin and alpha-2 macroglobulin concentration in scrum during pregnancy. Acta Obstet Gynecol Scand 1967; 46: 126-37.

8 Laurell CB. Alpha-1 antitrypsin deficiency and liver disease. In: Read AE cd. Modern trends in gastroenterology. 5th cd. London: Butterworth, 1975: 134.

9 Schumacher GFB, Pcarl MJ. Alpha antitrypsin in cervical mucus. Fertil Steril 1968; 19: 91-9.

10 Young C Jr, Headings VE, Bose S, Harden KA, Crockett ED Jr, Hackncy RL Jr. Alpha-1 antitrypsin level in sarcoidosis: relationship to discasc activity. Chest 1973; 64: 39-45.

11 Agarwal SK, Saha K. Scrum alpha-1 antitrypsin in various forms of leprosy. Indian J Med Res 1978; 68: 136-9.

12 Norn MS. Scrum immunoglobulin in endogenous uveitis. $\mathrm{Br} \mathrm{J}$ Ophthalmol 1976; 60: 299-301

13 Mori H. Immunoclectrophoresis study on the scrum of patients with uvcitis. Folia Ophthalmol Jpn 1968; 19: 372-5.

14 Ghose T, Quigley JH, Landrigan PL, Asif A. Immunoglobulins in aqueous humour and iris from patients with endogenous uveitis and paticnts with cataract. BrJ Op/thalmol 1973; 57: 897-9()3.

15 Arora PK, Miller HC, Aronson LD. Alpha-1 antitrypsin is an effector of immunologic stasis. Nature 1978; 274: 589-90.

16 Mancini G, Carbonara AO, Heremans JF. Immunochemical quantitations of antigens by radial immunodiffusion. Int $J$ Immunochem 1965; 2: 235-54.

17 Laurell CB. Is emphysema in alpha-1 antitrypsin deficiency a result of autodigestion? Scand J Clin Lab Invest 1971; 28: 1-3.

18 Brunt PW. Alpha-1 antitrypsin deficiency and liver discase. In: Read AE, ed. Modern trends in gastroenterology. 5th ed. London: Butterworths, 1975: 143.

19 Kulpati DD. Prevalence of alpha-1 antitrypsin deficiency in C.O.P.D. and some other illnesses. J Assoc Physicians India 1977: 7: 443-9.

20) Celikoğlu SI, Göksel FM, Bilgin T. A preliminary report on a study of scrum alpha-1 antitrypsin and immunoglobulin levels in lepromatous leprosy. Ann NY Acad Sci 1976; 272: 125-8.

21 Kucppers F, Black LF. Alpha-1 antitrypsin and its deficiency. Am Rev Resp Dis 1974; 110: 176-94.

22 Eriksson S. Pulmonary emphysema and alpha-1 antitrypsin deficiency. Acta Med Scand 1964; 175: 197-205.

23 Saari KM, Solja J, Hakli J. Genetic background of anterior uvcitis. Am J Ophthalmol 1981; 91: 711-20.

24 Grabner G, Pausch V, Mayr WR. Alpha-1 antitrypsin phenotypes in acutc anterior uveitis. Ophthalmic Res 1982; 14: 1-4.

25 Zirm M, Ritzinger I. The diagnostic and prognostic value of alpha-1 antitrypsin measurement in tear fluid. Klin Monatsbl Augenheilkd 1978; 173: 221-5.

26 Grabner G, Zehetbauer G, Bettlheim H. The blood aqueous humour barricr and its permeability for proteins of different molecular weight. Albrecht von Graefes Arch Klin Ophthalmol 1978; 207: 137-48.

27 Berman MB, Barber JC, Talamo RC, Langley CE. Corneal ulceration and the serum antiproteases. I. Alpha-1 antitrypsin. Invest Ophthalmol Visual Sci 1973; 12: 759-70.

28 Sharp HL. Alpha-1 antitrypsin deficiency and liver discase. In: Read AE, ed. Modern trends in gastroenterology. 5th cd. London: Butterworths, 1975: 140.

29 Ohlsson K. Interaction between human or dog leucocyte proteases and plasma protease inhibitors. Scand J Clin Lab Invest 1971; 28: 225-30.

30 Herman G, Miesscher PA. Differentiation of leucocyte fibrinolytic enzymes from plasmin by the use of plasmatic proteolytic inhibitors. Int Arch Allergy Appl Immunol 1965; 27: 34-41. 